Biochimica et Biophysica Acta, 412 (1975) 26-38

(C) Elsevier Scientific Publishing Company, Amsterdam - Printed in The Netherlands

BBA 37193

\title{
THE BEHAVIOR OF HOLO- AND APO-FORMS OF BOVINE SUPEROXIDE DISMUTASE AT LOW pH
}

\author{
JAMES A. FEE and W. D. PHILLIPS ${ }^{\star}$ \\ Department of Chemistry, Rensselaer Polytechnic Institute, Troy, N.Y. 12181, Biophysics Research \\ Division, Institute of Science and Technology, University of Michigan, Ann Arbor, Mich. 48105, and \\ Central Research Department, Experimental Station, E. I. DuPont de Nemours and Co., Wilmington, \\ Del. 19898 (U.S.A.)
}

(Received May 12th, 1975)

\section{SUMMARY}

1. Holo-superoxide dismutase from bovine erythrocytes has been shown to undergo a reversible structural modification in the $\mathrm{pH}$ 3-5 range.

2. The spectral alterations observed on changing from neutrality to $\mathrm{pH} 3$ were: a slight attenuation of the $680 \mathrm{~nm}$ absorbance; the loss of the $450 \mathrm{~nm}$ shoulder, apparent in the optical spectrum of the native protein; and a new band appeared at $330 \mathrm{~nm}$. The circular dichroism at $600 \mathrm{~nm}$ was essentially lost while a weak negative band appeared at approx. $380 \mathrm{~nm}$ and a positive band at $310 \mathrm{~nm}$.

3. The EPR spectrum was also modified on changing from the native to the low $\mathrm{pH}$ form: $A_{\|}$increased from $\approx 130$ to $\approx 150 \mathrm{G}, g_{\|}$remained unchanged at $\approx 2.27$, and $g_{\mathrm{m}}$ decreased from $\approx 2.09$ to $\approx 2.08$. The apparent linewidth remained essentially constant.

4. High resolution (220 MHz) PMR spectra of holo- and apoproteins revealed that the metals influence the three-dimensional structure of the protein.

5. PMR studies indicated that at $\mathrm{pH} 3$ the apoprotein existed almost entirely in a random coil form and that it assumed a compact well-ordered structure on returning to neutral $\mathrm{pH}$. The holoprotein maintained a compact, apparently dimeric, structure even at $\mathrm{pH} 3$.

\section{INTRODUCTION}

Superoxide dismutase has a molecular weight of 31000 and consists of two chemically identical subunits $[1,2]$. Each subunit binds a $\mathrm{Zn}^{2+}-\mathrm{Cu}^{2+}$ pair, the two metal ions are in very close proximity [3-5], and they form the active centers of the enzyme. The oxidation-reduction potential of the $\mathrm{Cu}^{2+}$ has been determined in the $\mathrm{pH}$ range 4-8.7 [6]. Above $\mathrm{pH} 5.5$ the redox potential decreases $0.059 \mathrm{~V}$ per $\mathrm{pH}$ unit,

* Present address: The Lord Rank Research Centre, Rank Hovis McDougall, Ltd, Lincoln Road, High Wycombe, Bucks, Great Britain. 
while below pH 5.5 there is very little dependence of $E_{\mathrm{m}}$ on $\mathrm{pH}$. The half reaction above $\mathrm{pH} 5.5$ can be described by:

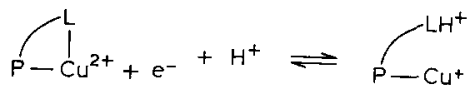

while below $\mathrm{pH} 5.5$ the ligand $\mathrm{L}$ may be protonated in the absence of reduction:

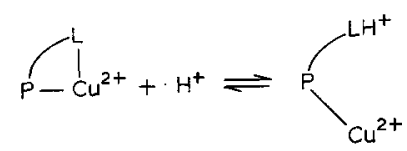

Our search for this equilibrium has led us to discover that both holo- and apoenzymes undergo conformational changes in the $\mathrm{pH} 3-5$ range. The spectral and sedimentation changes accompanying these alterations of the protein's structure are described.

\section{EXPERIMENTAL SECTION}

Materials. Superoxide dismutase was prepared by the method of McCord and Fridovich [7] and apoprotein was prepared as previously described $[4,7] .{ }^{2} \mathrm{H}_{2} \mathrm{O}$ $99.9 \%$ was obtained from BioRad Laboratories. All other chemicals were of highest commercial quality and where appropriate double distilled water was used.

Instrumentation. Routine $\mathrm{pH}$ measurements were made using a Heath Model EU-302A pH meter and a Fisher combined glass/ $\mathrm{Ag} / \mathrm{AgCl}$ electrode. The $\mathrm{pH}$ of PMR samples were measured with a Beckman $\mathrm{pH}$ meter and a specialized combination glass electrode. For solutions containing primarily ${ }^{2} \mathrm{H}_{2} \mathrm{O}$ the activity of the ${ }^{2} \mathrm{H}^{+}$was obtained from $\mathrm{p}^{2} \mathrm{H}=\mathrm{pH}$ meter reading $+0.4[8]$.

EPR spectra were obtained with a Varian E-9 EPR spectrometer operating at $X$-band with $100 \mathrm{kHz}$ field modulation. Spectra were recorded at temperatures near $100^{\circ} \mathrm{K}$ employing a device similar to that described by Hansen et al. [9] for temperature control.

PMR spectra were acquired with a Varian FFT $220 \mathrm{MHz}$ high resolution spectrometer operating in the continuous wave or in the Fourier transform mode at $220 \mathrm{MHz}$. Sample temperature was maintained at $37 \pm 1{ }^{\circ} \mathrm{C}$ in the described experiments. The signal to noise characteristic in the aromatic region of the spectra was enhanced by repeated collection of free induction decay patterns. All data manipulation was carried out with the Varian 620I computer. The general procedures have been described elsewhere [10].

Optical spectra were recorded with a Cary Model 14 dual beam spectrophotometer, and circular dichroism spectra were acquired with a Cary $60 \mathrm{~A}$ recording spectropolarimeter.

Sedimentation coefficients were measured using a Beckman Model E analytical ultracentrifuge operating at $60000 \mathrm{rev} . / \mathrm{min}$, and cells producing a synthetic boundary were used.

Preparation of samples for PMR measurements. Samples of native or apoprotein were exchanged into ${ }^{2} \mathrm{H}_{2} \mathrm{O}$ by one of two methods: (a) Dilution with ${ }^{2} \mathrm{H}_{2} \mathrm{O}$ and slow concentration under a stream of dry $\mathrm{N}_{2}$, or (b) freeze-drying followed by 
dissolution in ${ }^{2} \mathrm{H}_{2} \mathrm{O}$. No differences were observed in samples prepared by either procedure. Further, it should be emphasized that in properly treated samples of holoprotein, exchange into ${ }^{2} \mathrm{H}_{2} \mathrm{O}$ by either of the described techniques effects absolutely no change in the observed EPR spectrum (cf. ref. 11).

\section{RESULTS}

When the $\mathrm{pH}$ of an approx. $1 \mathrm{mM}$ solution of superoxide dismutase is lowered from neutrality to approx. 3, the blue-green color of the solution changes to one of clear cerulean blue. This is a reversible transformation as returning the $\mathrm{pH}$ to neutrality will restore the blue-green color. The changes in the visible optical spectrum are shown in Fig. 1 which describes some results of the titration from low to high $\mathrm{pH}$

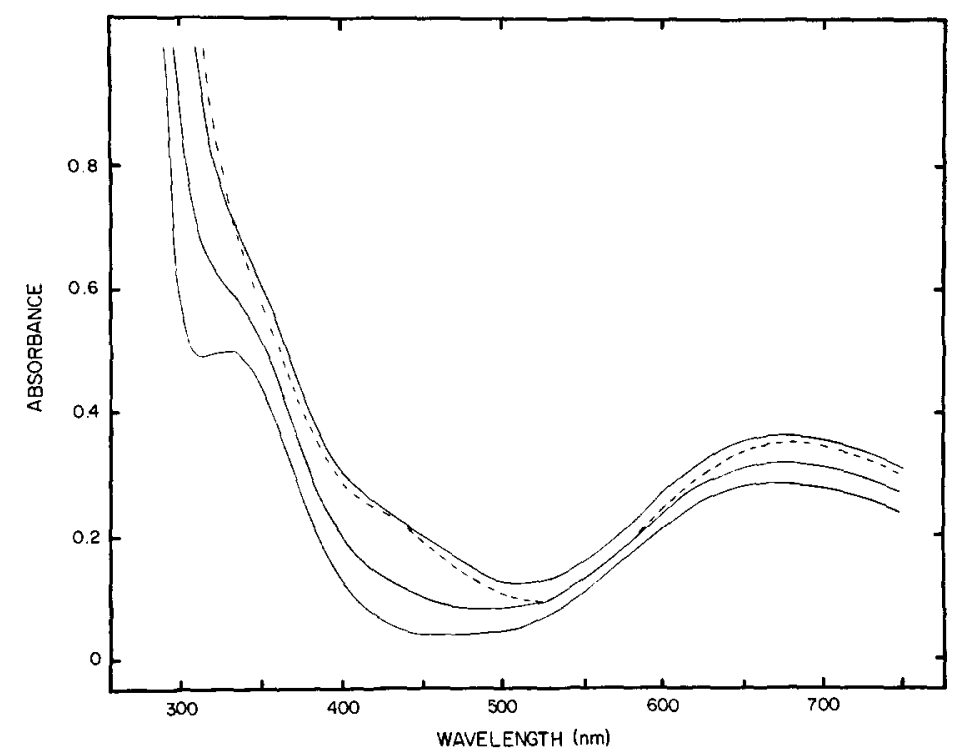

Fig. 1. Effect of pH on the visible optical spectrum of superoxide dismutase. Solid lines (- - ): Lower, holoenzyme adjusted from neutrality to a stable $\mathrm{pH}$ of 3.2 ; Middle, $\mathrm{pH}$ adjusted from 3.2 to 3.65 (stable); Upper, pH adjusted from 3.65 to 3.80. Dashed line (- - - ): After the last pH adjustment the sample was allowed to stand overnight, and it was then centrifuged to remove a small amount of insoluble denatured protein before the spectrum was recorded. Final pH 4.2. This spectrum corresponds to that of native protein.

and serves to demonstrate the reversibility. The spectral changes which occur on going to low $\mathrm{pH}$ are: approximately a $15 \%$ attentuation of absorbance in the region of $680 \mathrm{~nm}$, a complete loss of the strong shoulder at $450 \mathrm{~nm}$, the loss of strong absorbance below $350 \mathrm{~nm}$, and the appearance of a new but weaker absorption band at approx. $330 \mathrm{~nm}$. The change in color from blue-green to blue appears due to the loss of the band near $450 \mathrm{~nm}$.

Fig. 2 demonstrates the changes which occur in the visible circular dichroism spectrum on lowering the $\mathrm{pH}$. The strong positive band at $600 \mathrm{~nm}$ and presumably 


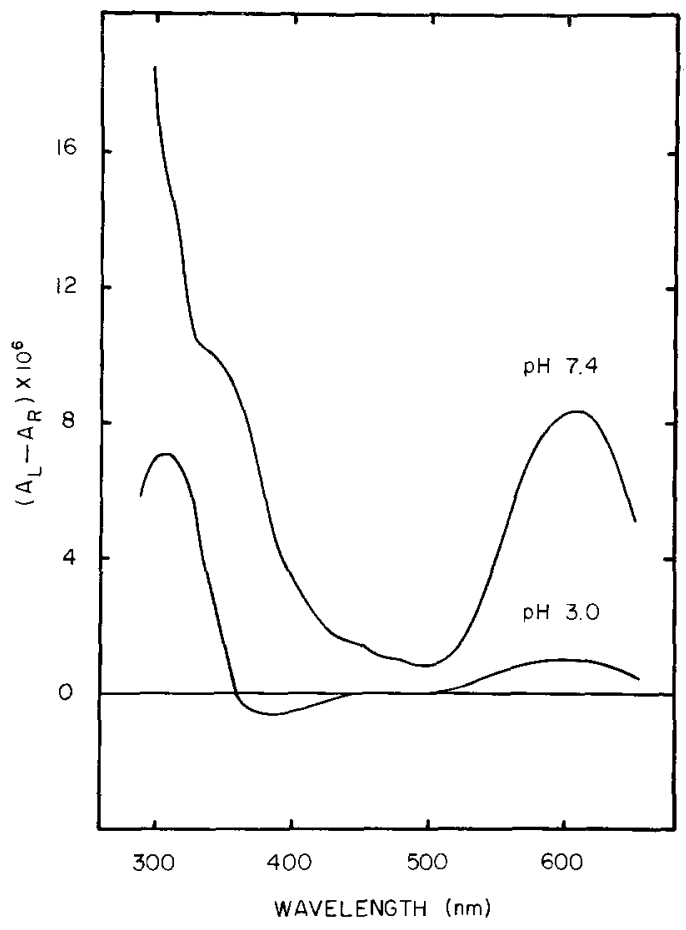

Fig. 2. Circular dichroism spectra of superoxide dismutase at pH 7.4 and 3.0.

the negative 750 band $^{\star}$ are both nearly lost. Indeed, the apparent dichroism in this region may only be due to some remaining high $\mathrm{pH}$ form of the molecule. Further, the strong positive shoulder at $350 \mathrm{~nm}$ is replaced by a weaker band near $310 \mathrm{~nm}$. The apparent but weak negative dichroism near $380 \mathrm{~nm}$ would be obscured if all enzyme was not converted to the low $\mathrm{pH}$ form. Thus, the $330 \mathrm{~nm}$ band in the optical spectrum may consist of one positively dichroic band below $330 \mathrm{~nm}$ and a negative band above $330 \mathrm{~nm}$.

The changes which occur in the low temperature EPR spectrum are shown in Fig. 3. On lowering the $\mathrm{pH}$, as indicated, the negative spectrum, having the parameters $A_{\|} \simeq 130 \mathrm{G}, g_{\|} \simeq 2.27$, and $g_{\mathrm{m}} \simeq 2.09$, was modified to one having the parameters, $A_{\|} \simeq 150 \mathrm{G}, g_{\|} \simeq 2.27$ and $g_{\mathrm{m}} \simeq 2.08$. The low $\mathrm{pH}$ spectrum also appears to be less rhombic $[12,13]$ than the neutral $\mathrm{pH}$ spectrum. At the lowest $\mathrm{pH}$ attempted with native protein a small amount of denaturation appeared to occur as evidenced by the amplified portion of the spectrum recorded at pH 2.9. Again, the EPR spectrum can be almost entirely returned to that characteristic of the native form by adjusting the $\mathrm{pH}$ toward neutrality. The lack of complete reversibility from $\mathrm{pH} 2.9$ is evident in Fig. 3 by the slightly lower resolution of the superhyperfine structure just above $3200 \mathrm{G}$, but this represents the modification of only a minor fraction of the total protein ${ }^{\star \star}$.

* The circular dichroism spectrum above $700 \mathrm{~nm}$ has been described in the advertising literature of Varian Associates: Circular 1A-621 (1972). The spectrum exhibits a negative band centered at approx. $750 \mathrm{~nm}$.

${ }^{\star *}$ The above results may be compared with those reported earlier by other authors [34]. 


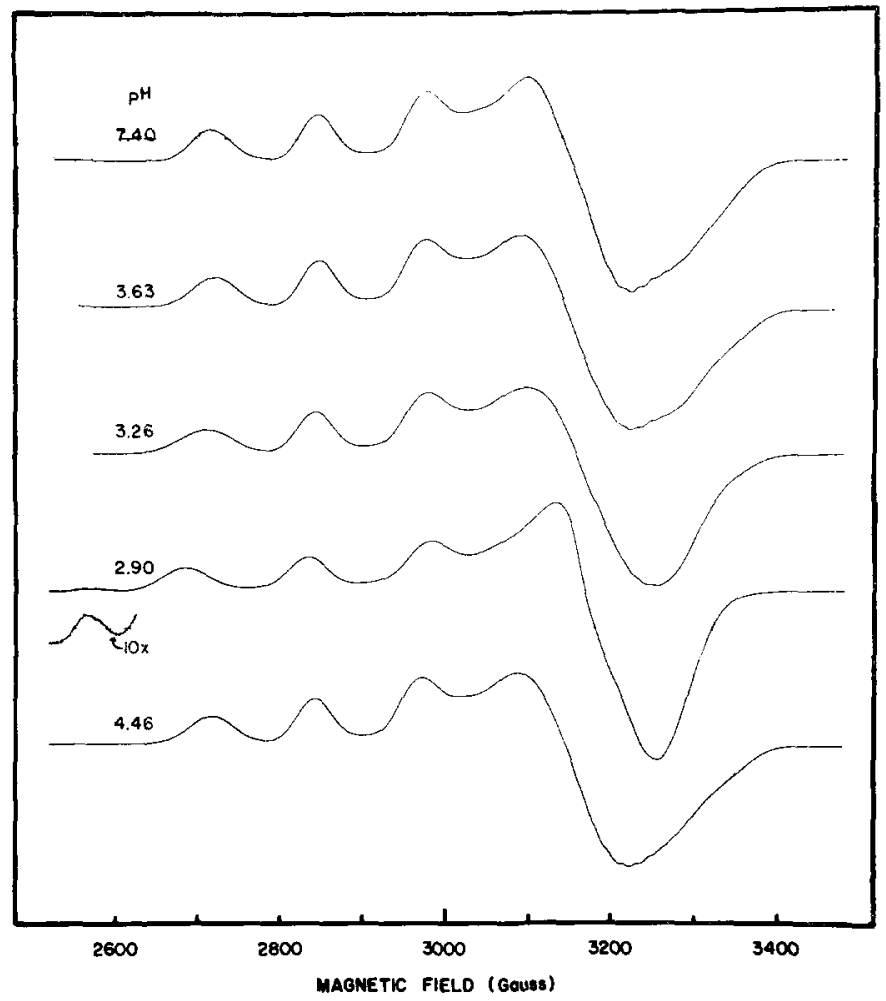

Fig. 3. Effect of $\mathrm{pH}$ on the EPR spectrum of superoxide dismutase. The experiment was carried out as follows: $1.6 \mathrm{ml}, 1.24 \mathrm{mM}$ dismutase in $10^{-4} \mathrm{M}$ potassium phosphate buffer, $\mathrm{pH} 7.4$, was titrated with $1 \mathrm{M} \mathrm{H}_{3} \mathrm{PO}_{4}$. During titration the sample was stirred. $84 \mu \mathrm{l}$ of acid was required to lower the $\mathrm{pH}$ to 2.90 . When the $\mathrm{pH}$ had stabilized at a desired value both optical and EPR spectra were recorded using the same sample. This required about $10 \mathrm{~min}$ after which the $\mathrm{pH}$ had generally risen less than 0.1 unit. After titration to $\mathrm{pH} 2.90$ the $\mathrm{pH}$ was returned to 4.46 by addition of $\mathrm{NaOH}$. EPR spectra were recorded at $100{ }^{\circ} \mathrm{K}$ with the following instrumental settings: Modulation amplitude, $10 \mathrm{G}$; time constant, $0.1 \mathrm{~s}$; field sweep, $500 \mathrm{G} / \mathrm{min}$.

In spite of its essential reversibility the low $\mathrm{pH}$ transition of native superoxide dismutase is accompanied by considerable hysteresis, as demonstrated by Fig. 4 in which relative optical and EPR changes in the $\mathrm{pH}$ region of the transition are presented. The underlying basis of the hysteresis is probably related to the slowness of the $\mathrm{pH}$-dependent structural transition on going from high to low $\mathrm{pH}$. Thus, after addition of acid at room temperature several minutes are required to achieve a nominally stable $\mathrm{pH}$ (up to $30 \mathrm{~min}$ ), but the time course of the $\mathrm{pH}$ change, particularly over longer periods, has not been studied. In the several experiments which were carried out, a comparable time dependence was not observed on titration from low to high $\mathrm{pH}$.

The question of whether the native dimeric molecule became dissociated at low $\mathrm{pH}$ values was studied by measuring the effective sedimentation coefficient of holoenzyme in $0.1 \mathrm{M} \mathrm{NaCl}$ at $\mathrm{pH} \mathrm{4,3.5} \mathrm{and} \mathrm{3;} S_{\text {eff }}$ decreased only from $2.8 \mathrm{~S}$ at $\mathrm{pH} 4$ to $2.4 \mathrm{~S}$ at $\mathrm{pH} 3$ (Fig. 5). This strongly suggests that significant dissociation into monomers did not occur. 

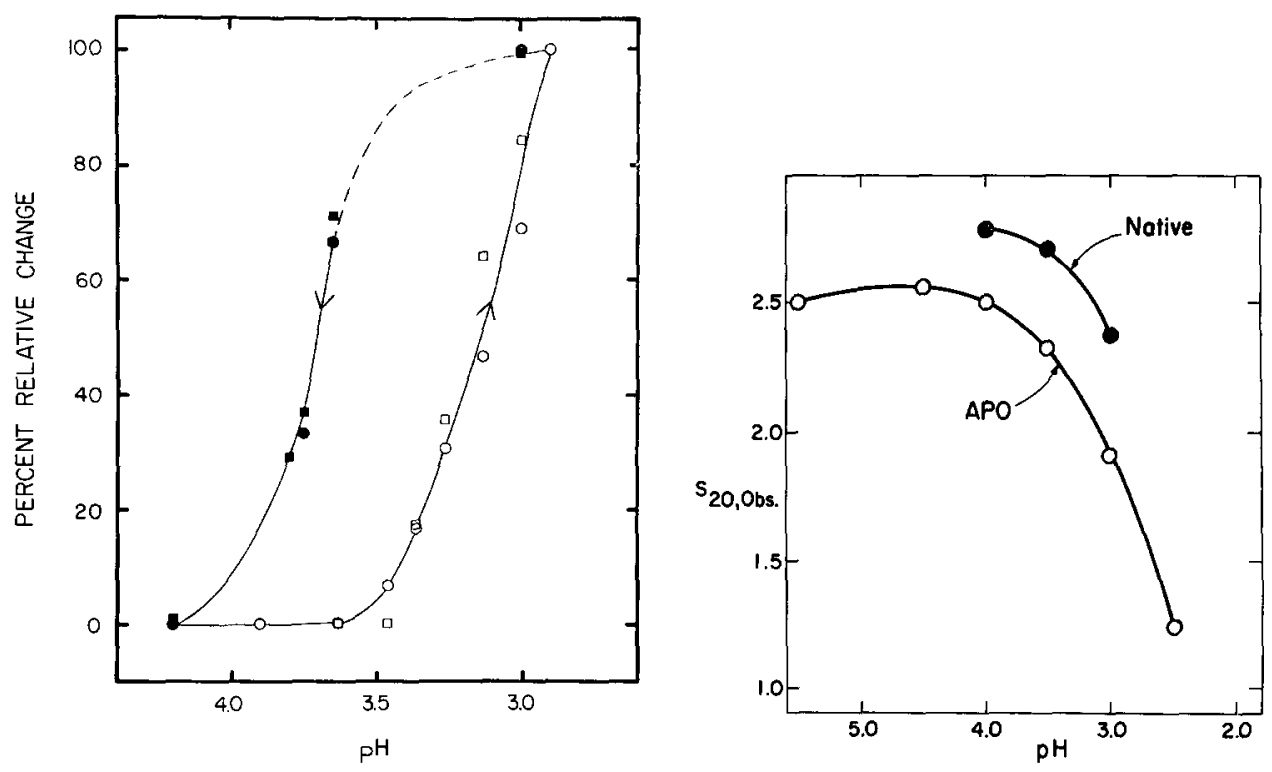

Fig. 4. Demonstration of the hysteresis effect in the low $\mathrm{pH}$ titration of superoxide dismutase. The experiment described in the legend of Fig. 3. Changes in absorbance at $450 \mathrm{~nm}$ in the down $(O)$ and (C) up titration. Increase in EPR signal intensity at $3250 \mathrm{G}$ in the down ( $\square$ ) and up ( $\square$ ) titration. Corrections for volume changes were made. The lines are not derived from any theory.

Fig. 5. The effect of $\mathrm{pH}$ on the sedimentation coefficients of holo- and apo-superoxide dismutases. The concentration of protein was $8 \mathrm{mg} / \mathrm{ml}$ in $0.1 \mathrm{M} \mathrm{NaCl}$, the temperature was $20^{\circ} \mathrm{C}$, and the $\mathrm{pH}$ of each sample was measured after standing overnight at room temperature. Plots of $\ln r(t) / r\left(t_{0}\right)$ vs $t$ were perfectly linear in all cases. The ratio $r(t) / r\left(t_{0}\right)$ was obtained using a comparator. No corrections to the observed sedimentation coefficients were made.

High resolution PMR spectra (Fig. 6) of holoprotein taken in the range $\mathrm{p}^{2} \mathrm{H}$ 6.9-3.4 demonstrate that the three-dimensional structure of the polypeptide chains is substantially preserved even at $\mathrm{p}^{2} \mathrm{H}$ 3.4. There are, however, changes in the spectrum which suggest conformational alterations on going to low $\mathrm{pH}$; for examples, the sharpening of the resonance envelopes near $1,7.5$, and $8.5 \mathrm{ppm}$ which probably reflect overall changes in protein structure as well as the specific changes occurring near the metal binding site.

The behavior of the apoprotein has also been studied by PMR spectroscopy (Fig. 7). Above $\mathrm{p}^{2} \mathrm{H} \approx 5$ the apoprotein possesses a compact conformation evidenced by the broad resonance envelopes in both aromatic and aliphatic regions. Its overall conformation, however, appears to differ somewhat from that of the holoprotein. This is best illustrated by comparing the spectra of holo- and apoproteins in the $6.5-7.5 \mathrm{ppm}$ region. Here the spectrum of apoprotein has a distinct doublet structure while only a single broad line can be seen in the spectrum of holoprotein. The generally higher resolution observed in the apospectrum compared to the holo spectrum may arise from two sources: (a) broadening of resonances by the paramagnetic $\mathrm{Cu}^{2+}$ [14], and (b) a generally "looser" or a conformationally more dynamic structure resulting in a greater averaging of anisotropic magnetic interactions [15]. Previous 


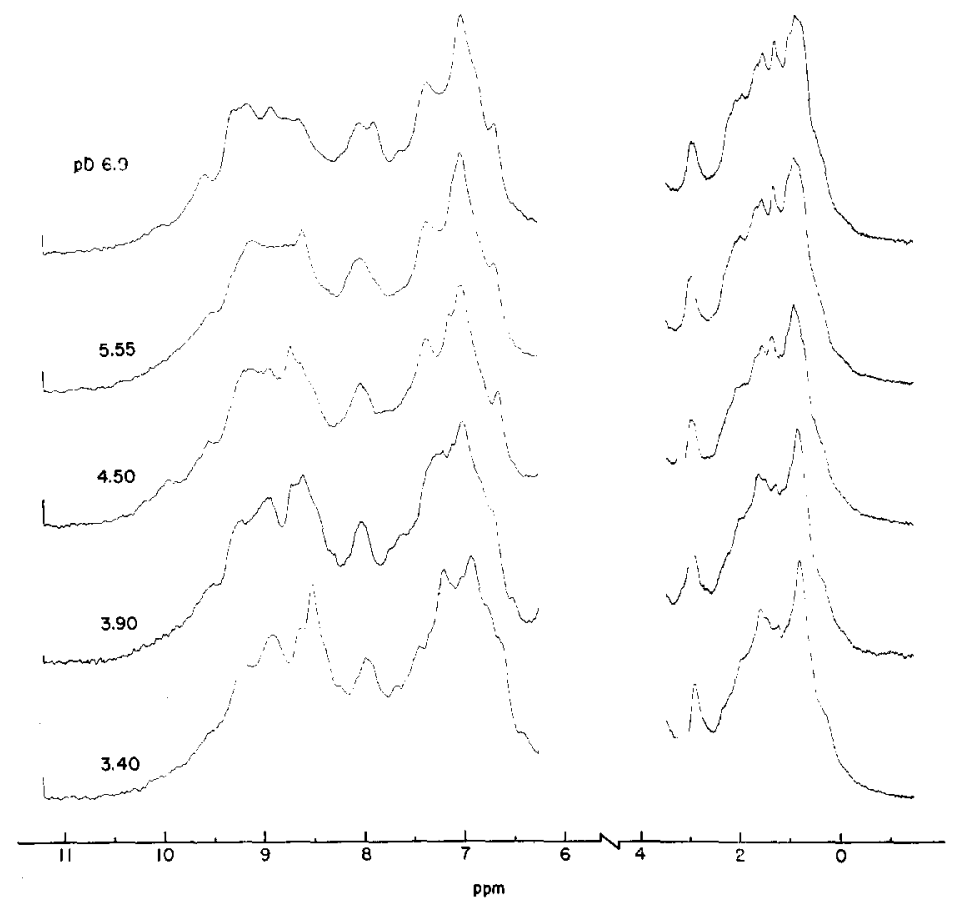

Fig. 6. The effect of $\mathrm{pH}$ on the $220 \mathrm{MHz}$ PMR spectrum of superoxide dismutase. The concentration of the samples used was approx. $60 \mathrm{mg} / \mathrm{ml}$. $\mathrm{pH}$ adjustments were made by adding small amount of $\mathrm{NaO}^{2} \mathrm{H}$ or ${ }^{2} \mathrm{HCl}$ with rapid stirring. The frequency scale based on the $\mathrm{HO}^{2} \mathrm{H}$ line which was determined to be $1020 \mathrm{~Hz}$ downfield from 2,2-dimethyl-2-silapentane-5-sulforate at $37^{\circ} \mathrm{C}$. The aliphatic region (1-4 ppm) was recorded in the continuous wave mode. The aromatic region $(6-11 \mathrm{ppm})$ was recorded in the FT mode and recorder output is normalized to the highest peak in this spectral region. The large $\mathrm{HO}^{2} \mathrm{H}$ signal and spinning side bands have been deleted.

results on the reconstitution of holoprotein from apoprotein and metal ions have been interpreted in terms of a structural difference between the two forms [3].

When the $\mathrm{pH}$ of a solution of apoprotein is lowered from $\mathrm{p}^{2} \mathrm{H} 5.7$ to 4.0 the PMR spectrum changes dramatically (Fig. 7) from that characteristic of a compactfolded structure to one characteristic of the random coil structure [16, 17]. Measurement of the sedimentation coefficient of apoprotein over the $\mathrm{pH}$ range 5.5-2.5 revealed a decrease of $S_{\text {efr }}$ from $2.56 \mathrm{~S}$ at pH 4.5 to $1.29 \mathrm{~S}$ at pH 2.5 (Fig. 5). Clearly such a large change in $S_{\text {eff }}$ is consistent with the occurrence of monomerization, and the PMR spectrum suggests dissociation of the subunits into randomly coiled peptide chains.

It is noteworthy that readily detectable changes do not occur in the optical spectrum above $250 \mathrm{~nm}$ or in the circular dichroism spectrum above $200 \mathrm{~nm}$. We have thus used PMR to examine the reversibility of the low $\mathrm{pH}$ transition of apoprotein. When base is added to a concentrated $(60 \mathrm{mg} / \mathrm{ml})$ solution of apo-superoxide dismutase so as to adjust the $\mathrm{pH}$ from say 3 to 5 , there is an immediate and apparently irreversible precipitation of the protein from solution. If, however, base is added so as to effect only very small increases in $\mathrm{pH}$ and this is done slowly then no precipitation 


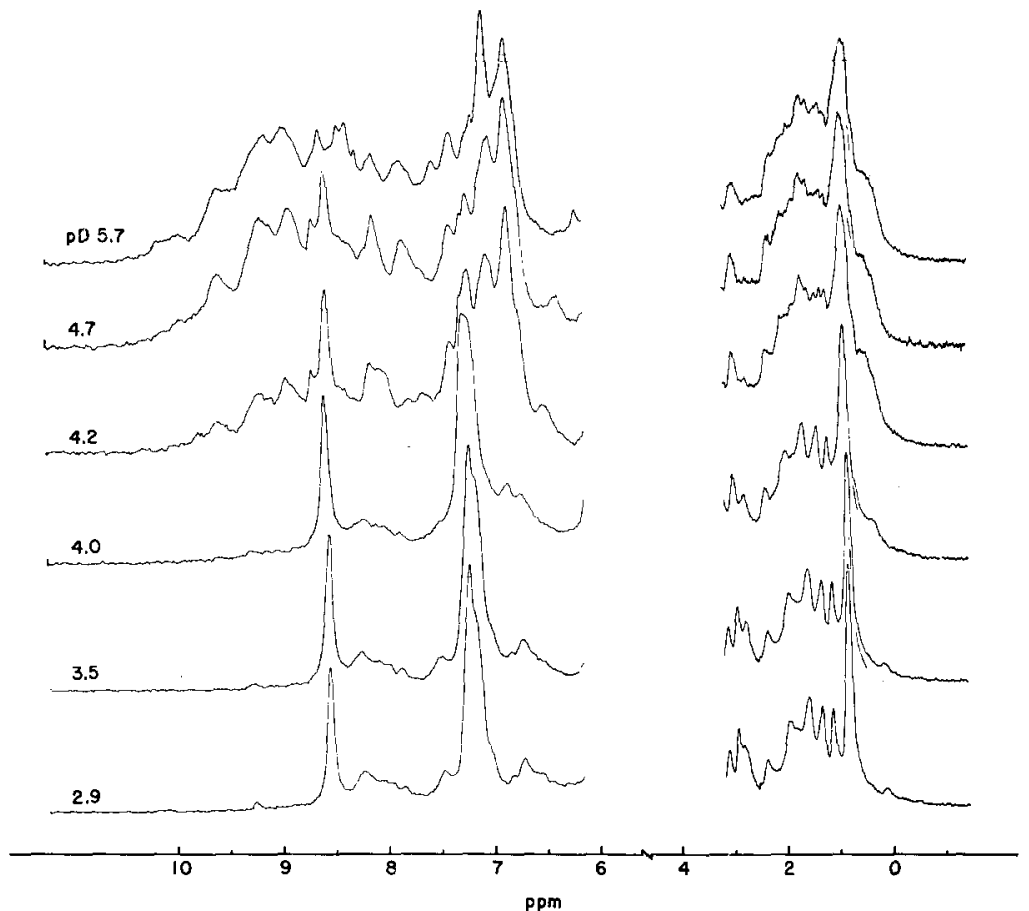

Fig. 7. Effect of lowering $\mathrm{p}^{2} \mathrm{H}$ from 5.7 to 2.9 on the $220 \mathrm{MHz}$ PMR of apo-superoxide dismutase. Conditions and procedures similar to those described in legend to Fig. 6.

occurs and the transition seems to be substantially reversed; the results of a PMR experiment are shown in Fig. 8. The reversibility can be seen most readily by comparing the $\mathrm{p}^{2} \mathrm{H} 5.7$ spectrum with the $\mathrm{p}^{2} \mathrm{H} 5.9$ spectrum in Fig. 8. Note that in the field range $7.5-1.0 \mathrm{ppm}$ these two spectra are substantially the same. Below 7.5 ppm the apparent differences between these two spectra are believed to be due to a greater portion of $\mathrm{N}-\mathrm{H}$ exchange to $\mathrm{N}^{-2} \mathrm{H}$ in the $\mathrm{p}^{2} \mathrm{H} 5.7$ spectrum [18]. This deduction is justified by comparing the $\mathrm{p}^{2} \mathrm{H} 5.7$ spectrum from Fig. 7 with the $\mathrm{p}^{2} \mathrm{H} 5.7$ spectrum in Fig. 8. The latter was obtained from a dilute sample of apoprotein which had been brought to $\mathrm{pH} 3$ and returned to neutral $\mathrm{pH}$ in water prior to being concentrated and exchanged into ${ }^{2} \mathrm{H}_{2} \mathrm{O}$ and is thus directly comparable to the $\mathrm{p}^{2} \mathrm{H} 5.7$ spectrum shown in Fig. 7. Clearly the low pH transition is reversible if precautions are taken to avoid precipitation either by increasing the $\mathrm{pH}$ very slowly or by using a dilute solution.

To further test the supposition that the individual polypeptide chains assume the properties of random coils at low $\mathrm{pH}$ we have computed a "random coil" spectrum, utilizing published line positions and widths [17] in conjunction with the amino acid composition [1,2]. Somewhat arbitrarily the resonance position of the protonated His C-4 proton was taken as $7.30 \mathrm{ppm}$, just below the published value of $7.26 \mathrm{ppm}$ for the aromatic protons of phenylalanine. Bradbury and Scheraga [19] have reported that the C-4 proton of protonated histidine was observed near 7.3-7.4 ppm, and McDonald and Phillips [20] in discussing the His C-4 resonances of ferrocytochrome $c$ indicate considerable latitude in the position of this proton. In general, the correspondence between the calculated and observed spectra were good. The peak positions 


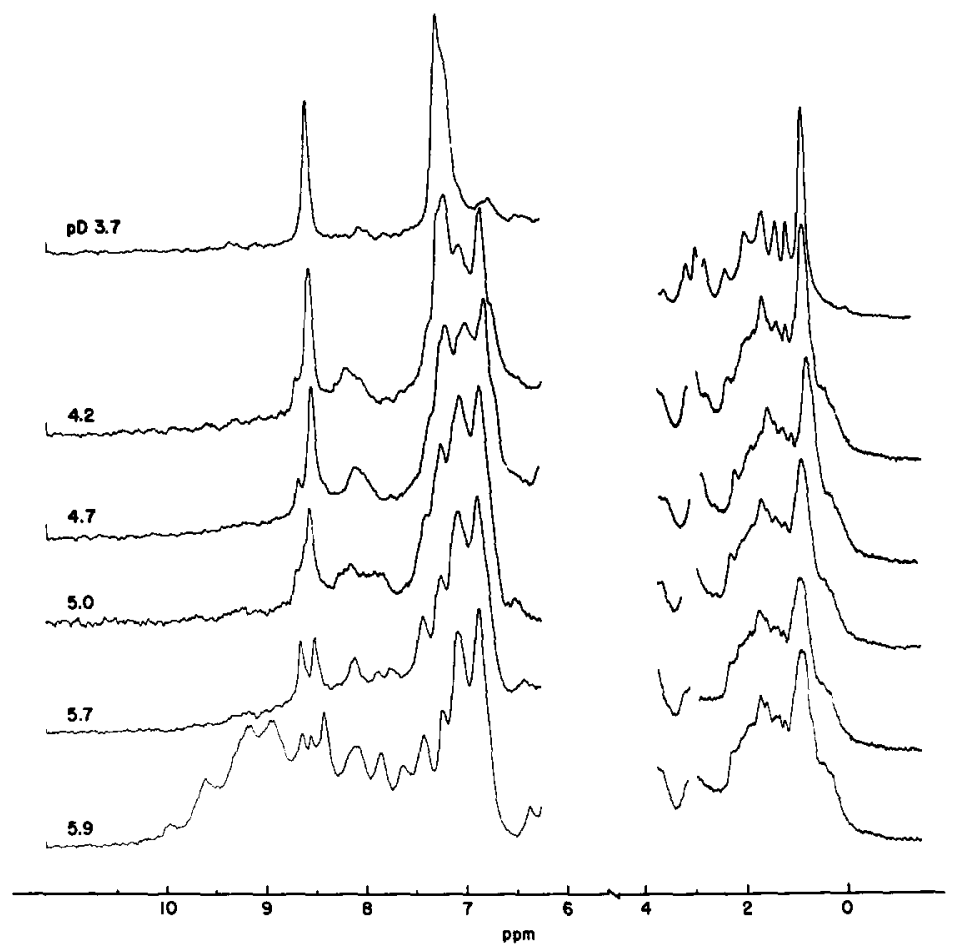

Fig. 8. Effect of raising $\mathrm{p}^{2} \mathrm{H}$ from 3.7 to 5.7 on the $220 \mathrm{MHz}$ PMR spectrum of apo-superoxide dismutase. Conditions and procedures as in Fig. 6 . The lower spectrum was obtained from a sample which had been adjusted to $\mathrm{pH} 3$ in water followed by readjustment to $\mathrm{pH} 6$ and exchanged into ${ }^{2} \mathrm{H}_{2} \mathrm{O}$ by the freeze-dry dissolution technique.

and relative intensities of the two spectra are compared in Table I. It can be seen that the resonance positions are only slightly different and that the relative intensities are comparable, particularly in the aromatic region. The small differences in resonance positions may reflect the fact that the parameters used were for neutral $\mathrm{p}^{2} \mathrm{H}$ at elevated temperatures [17]. The small differences in relative intensities suggest that a complete randomization of the polypeptide chain had not occurred.

\section{DISCUSSION}

\section{Holoprotein}

The above results demonstrate clearly that holo-superoxide dismutase undergoes a structural change in the immediate vicinity of the $\mathrm{Cu}^{2+}$ on lowering the $\mathrm{pH}$ from neutrality to approx. 3 , and this results in modifications of the optical, circular dichroism, and EPR spectra. A possible interpretation of the low $\mathrm{pH}$ behavior can be made in terms of the recently determined structure of superoxide dismutase.

The Richardsons' group has demonstrated by X-ray crystallographic measurements that an imidizolium anion serves as a bridging ligand between $\mathrm{Zn}^{2+}$ and $\mathrm{Cu}^{2+}$ [21]. The constant for the ionization of neutral imidazole to its anion is approx. 14 [22] while the analogous ionization constant for the imidazole ring of dihistidyl- $\mathrm{Cu}^{2+}$ 
TABLE I

COMPARISON OF OBSERVED AND CALCULATED* PMR SPECTRA OF SUPEROXIDE DISMUTASE AT LOW $\mathrm{pH}$

* Parameters used were: Residue, intensity, resonance (ppm), full line width at half height $(\mathrm{Hz})$; Leu- $\mathrm{CH}_{3}, 40,0.886,15$; Ile- $\mathrm{CH}_{3}, 30,0.832,20 ; \mathrm{Val}-\mathrm{CH}_{3}, 35.2,0.932,17$; Thr $-\mathrm{CH}_{3}, 18.7,1.23,16$; Ala- $\mathrm{CH}_{3}, 16.7,1.41,18$; Lys- $\delta \mathrm{CH}_{2}+\beta \mathrm{CH}_{2}, 13.3,1.68,30$; Met- $\mathrm{CH}_{3}, 30$, 2.06, 10; Tyr-ortho $\mathrm{H}$, 11.8, 6.82, 17; Tyr-meta H, 11.8, 7.09, 17; Phe (aromatic), 16.7, 7.26, 30; His C-4, 10, 7.30, 10; His $\mathrm{C}-2,10,8.56,10$. Except for His C-4 al' parameters taken from ref. 17. A Lorentzian line shape was assumed.

\begin{tabular}{|c|c|c|c|c|c|}
\hline \multicolumn{2}{|l|}{ Observed } & \multicolumn{2}{|c|}{ Calculated } & \multirow[t]{2}{*}{ Assignment } & \multirow{2}{*}{$\begin{array}{l}\text { Number of } \\
\text { contributing residues } \\
\text { per subunit [1] }\end{array}$} \\
\hline $\begin{array}{l}\text { Line } \\
\text { position }\end{array}$ & $\begin{array}{l}\text { Relative } \\
\text { intensity }\end{array}$ & $\begin{array}{l}\text { Line } \\
\text { position }\end{array}$ & $\begin{array}{l}\text { Relative } \\
\text { intensity }\end{array}$ & & \\
\hline \multicolumn{6}{|c|}{ Aliphatic region } \\
\hline 0.77 & 100 & 0.92 & 100 & $\mathrm{CH}_{3^{-}}$of Leu, Ile, Val & $8,9,15$ \\
\hline 1.09 & 40 & 1.23 & 35 & $\mathrm{Thr}-\mathrm{CH}_{3}$ & 12 \\
\hline 1.32 & 41 & 1.41 & 24 & Ala- $\mathrm{CH}_{3}$ & 9 \\
\hline 1.57 & 44.7 & 1.68 & 19.4 & Lys- $\delta, \beta \mathrm{CH}_{2}$ & 10 \\
\hline 1.94 & 34.8 & 2.06 & 11.4 & Met- $\mathrm{CH}_{3}$ & 1 \\
\hline \multicolumn{6}{|c|}{ Aromatic region } \\
\hline 6.75 & 20 & 6.94 & 10.4 & Tyr (ortho) & 1 \\
\hline $7.05(\mathrm{ws})$ & & 7.10 & & Tyr (meta) & 1 \\
\hline $7.15(\mathrm{~s})$ & 81 & 7.27 & & Phe (aromatic) & 4 \\
\hline 7.22 & 100 & 7.30 & 100 & $\mathrm{His} \mathrm{C}-4$ & 8 \\
\hline 8.55 & 58 & 8.56 & 61 & His $\mathrm{C}-2$ & 8 \\
\hline
\end{tabular}

has been measured to be approx. $11.7[23,24]$. The latter $\mathrm{p} K_{\mathrm{a}}$ is sufficiently high to account for the linear decrease of the midpoint potential, $E_{\mathrm{m}}$, of the $\mathrm{Cu}^{2+} / \mathrm{Cu}^{+}$couple $\mathrm{pH}$ between 5.5 and 8.7 as shown in Fig. 3 of ref. 6. It is reasonable to assume that in the reduced form of the protein the imidazolium anion becomes dissociated from one of the metal ions and binds a proton. Below pH $5.5 E_{\mathrm{m}}$ becomes substantially independent of $\mathrm{pH}$ suggesting that the group responsible for the $\mathrm{pH}$ dependence of $E_{\mathrm{m}}$ above $\mathrm{pH} 5.5$ binds a proton in the absence of $\mathrm{Cu}^{2+}$ reduction below pH 5.5. In the context of this assumption, the spectral manifestations of the low $\mathrm{pH}$ transition can be interpreted in terms of the equilibrium

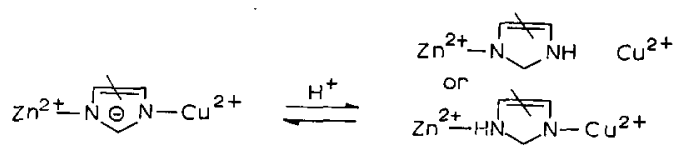

where the imidazolium anion becomes protonated with concomitant dissociation from one of the metal ions. On the basis of the present observations it is not possible to distinguish between the two cases, but a simple consideration of the relative affinity constants suggests that the imidazole would remain coordinated to $\mathrm{Cu}^{2+}$ rather than $\mathrm{Zn}^{2+}[25]$.

It is useful to compare the low $\mathrm{pH}$ optical spectrum with that of a derivative 
of the protein in which the $\mathrm{Zn}^{2+}$ binding site is unoccupied but $\mathrm{Cu}^{2+}$ is bound in the $\mathrm{Cu}^{2+}$ site, $2 \mathrm{Cu}^{2+}$-protein [26, 27]. It has been shown that the optical spectrum of this species lacks the absorption band near $450 \mathrm{~nm}$, observed in the native spectrum, just as does the low $\mathrm{pH}$ form of the native protein. The $450 \mathrm{~nm}$ absorption can be restored to the $2 \mathrm{Cu}^{2+}$ derivative when $\mathrm{Zn}^{2+}, \mathrm{Hg}^{2+}, \mathrm{Cd}^{2+}$ [26] or $\mathrm{Cu}^{2+}$ [27] binds to the $\mathrm{Zn}^{2+}$ site, and this suggests that $450 \mathrm{~nm}$ absorption depends on the presence of the metal bridging imidazolium anion. The loss of this band in the native protein at low $\mathrm{pH}$ suggests but does not prove that the bridging imidazolium anion becomes protonated at low $\mathrm{pH}$.

The low $\mathrm{pH}$ transition does not consist only of the above-mentioned ionization. The PMR spectra (Fig. 6) indicate minor structural alterations associated with both aliphatic and aromatic residues. Further, the equilibrium must be strongly linked to other ionizations as evidenced by the qualitative observation that the binding of a substantial number of protons occurs subsequent to a slower process which may be a general conformational change resulting from the proton-induced structural change at the active center. A conformational modification affecting the frictional coefficient of the molecule could account for the small decrease in the sedimentation coefficient; the decrease, notably, is only slightly larger than that obtained on removing the metal ions (Fig. 5).

\section{Apoprotein}

Near neutral $\mathrm{pH}$ the apoprotein exists as a folded structure in which the two subunits are clearly associated as evidenced by the sedimentation coefficient. The PMR spectrum of "native" apoprotein indicates a somewhat different three-dimensional structure than that of holoprotein, and the metal ions clearly play an important role in determining the protein's structure as has already been reported by Stokes et al. [28]. The effect of bound metals on the stability of the protein is particularly evident at low $\mathrm{pH}$ where the apoprotein is largely denatured, while this disruption of the compact globular structure is prevented by the bound metal ions. Previous studies have shown that metals enhance the thermal stability of the apoprotein near neutral $\mathrm{pH}[29]$ and its stability toward denaturing solvents [30].

At low $\mathrm{pH}$ the sedimentation coefficient has substantially decreased, from $2.56 \mathrm{~S}$ to $1.29 \mathrm{~S}$. Assuming a random coil of 140 amino acids, the sedimentation coefficient in $6 \mathrm{M}$ guanidine $\cdot \mathrm{HCl}$ would be expected to be $S^{\circ}=0.45 \mathrm{~S}$ at zero protein concentration [31]. If we assume the same empirical function of $S^{\circ}$ for a random coil in guanidine $\cdot \mathrm{HCl}$ holds in $0.1 \mathrm{M} \mathrm{NaCl}$ and correct for the difference in buoyant density, $S^{\circ}$ should be slightly greater than $0.8 \mathrm{~S}$ for the subunit of superoxide dismutase. On this basis the $S_{\text {eff }}$ value obtained is consistent with substantial denaturation toward a random structure. The observed PMR spectrum supports this contention but some three-dimensional structure appears to remain as evidenced by the broad underlying resonance envelopes remaining even at $\mathrm{p}^{2} \mathrm{H}$ 2.9. Thus, a small amount of "core" structure probably remains.

\section{Some comments on the mechanism of reconstitution}

The resolution of metals from protein generally involves treatment of the holoprotein with EDTA at $\mathrm{pH} 3.8$ [7], and this procedure, which yields the starting material for reconstitution, has been shown to effectively remove $90-99 \%$ of both 
metals $[4,26,32,33]$. Reconstitution to native protein either partially or fully has been effected over a range of conditions. Weser et al. [33] were able to obtain a partial yield of native protein in a mixture, judging from published EPR spectra, of nonnative $\mathrm{Cu}^{2+}$-protein complexes at $\mathrm{pH} 7.2,20^{\circ} \mathrm{C}, 10 \mathrm{~min}$ with stoichiometric ratios of metal to protein. We found previously [3] that dialysis of apoprotein against a dilute metal solution containing a 10 -fold excess of metals led to about a $70 \%$ yield of native protein having no non-native $\mathrm{Cu}^{2+}$-protein contaminants. The time required was approx. $30 \mathrm{~h}$ and the optimum $\mathrm{pH}$ was near 5. Beem et al. [26] have recently described a procedure which involves slow addition of 2 molar equivalents of $\mathrm{Cu}^{2+}$ to apoprotein maintained at $\mathrm{pH} 3.8$ followed by direct addition of 2 molar equivalents of $\mathrm{Zn}^{2+}$. This procedure returns native protein in very high yield.

Since a substantial fraction of apoprotein appears to exist in a monomeric, random coil state at $\mathrm{pH} 3.8$ the reconstitution process requires a return of this to a folded structure. The results of Beem et al. [26] suggest that the highest yield of reconstituted protein can be obtained if the refolding is effected in the presence of $\mathrm{Cu}^{2+}$ at a $\mathrm{pH}$ where apoprotein can dynamically unfold and refold, the $\mathrm{Cu}^{2+}$ stabilizing the so-called $2 \mathrm{Cu}^{2+}$-protein $[26,27]$ which readily binds $\mathrm{Zn}^{2+}$ to form native protein $[3,26]$. The lower yields obtained when reconstitution was effected at higher $\mathrm{pH}$ values can be explained by a refolding of apoprotein to a globular structure which slowly and only partly rearranges to the native structure in the presence of $\mathbf{Z n}^{2+}$ and $\mathrm{Cu}^{2+}$.

\section{ACKNOWLEDGEMENTS}

We would like to thank Dr K. T. Potts for the generous use of the Cary Model 14 spectrophotometer, Dr T. E. King for help in running the circular dichroism spectra, Mr Fran Ferrari for recording the PMR spectra, Mr John Trojanowski for carrying out the sedimentation velocity measurements, Dr W. R. Dunham for aid in computing the PMR spectra, and Dr I. Fridovich for forwarding the correct amino acid composition of bovine superoxide dismutase prior to publication. This work is supported in part by a grant from U.S.P.H.S. (GM 18869).

\section{REFERENCES}

1 Steinman, H. M., Naik, V. R., Abernethy, J. L. and Hill, R. L. (1974) J. Biol. Chem. 249, 73267338

2 Abernethy, J. L., Steinman, H. M. and Hill, R. L. (1974) J. Biol. Chem. 249, 7339-7347

3 Fee, J. A. (1973) Biochim. Biophys. Acta 295, 107-116

4 Fee, J. A. (1973) J. Biol. Chem. 248, 4229-4234

5 Rotilio, G., Calabrese, L., Mondovi, B. and Blumberg, W. E. (1974) J. Biol. Chem. 249, 31573160

6 Fee, J. A. and DiCorleto, P. E. (1973) Biochemistry 12, 4893-4899

7 McCord, J. M. and Fridovich, I. (1969) J. Biol. Chem. 244, 6049-6055

8 Glasoe, P. K. and Long, F. A. (1960) J. Phys. Chem. 64, 188-190

9 Hansen, R. E., Kalal, T. T. and Beinert, H. (1967) Anal. Biochem. 20, 40-45

10 McDonald, C. C. and Phillips, W. D. (1967) J. Am. Chem. Soc. 89, 6332-6341

11 Rotilio, G., Finazzi-Agro, A., Calabrese, L., Bossa, F., Guerrieri, P. and Mondovi, B. (1971) Biochemistry 10, 616-621

12 Fee, J. A. and Gaber, B. P. (1971) Fed. Proc. 30, no. 1409 
13 Rotilio, G., Morpurgo, L., Giovagnoli, C., Calabrese, L. and Mondovi, B. (1972) Biochemistry $11,2187-2192$

14 Swift, T. J. and Connick, R. E. (1962) J. Chem. Phys. 37, 307-320

15 Sternlicht, H. and Wilson, D. (1967) Biochemistry 6, 2881-2892

16 McDonald, C. C. and Phillips, W. D. (1969) J. Am. Chem. Soc. 91, 1513-1521

17 McDonald, C. C. and Phillips, W. D. (1970) Biol. Macromol. Ser. 4, 1-48

18 Glickson, J. D., McDonald, C. C. and Phillips, W. D. (1969) Biochem. Biophys. Res. Commun. 35, 492-498

19 Bradbury, J. H. and Scheraga, H. A. (1966) J. Am. Chem. Soc. 88, 4240-4246

20 McDonald, C. C. and Phillips, W. D. (1973) Biochemistry 12, 3170-3186

21 Richardson, J. S., Thomas, K. A., Rubin, B. H. and Richardson, D. C. (1975) Proc. Natl. Acad. Sci. U.S. 72, 1349-1353

22 Yagil, G. (1967) Tetrahedron 23, 2855-2861

23 Morris, P. J. and Martin, R. B. (1970) J. Am. Chem. Soc. 92, 1543-1546

24 Martin, R. B. (1974) Proc. Natl. Acad. Sci. U.S. 71, 4346-4347

25 Sillen, L. G. and Martell, A. E. (1964) Stability Constants of Metal Ion Complexes, Chemical Society Special Publication No. 17, Table 144, p. 388

26 Beem, K. M., Rich, W. E. and Rajagopalan, K. V. (1974) J. Biol. Chem. 249, 7298-7305

27 Fee, J. A. and Briggs, R. G. (1975) Biochim. Biophys. Acta 400, 439-450

28 Stokes, A. M., Hill, H. A. O., Bannister, W. H. and Bannister, J. V. (1973) FEBS Lett. 32, 119 123

29 Forman, H. J. and Fridovich, I. (1973) J. Biol. Chem, 248, 2645-2649

30 Fee, J. A., Natter, R. and Baker, G. S. T. (1973) Biochim. Biophys. Acta 295, 96-106

31 Tanford, C., Kawahara, K. and Lapanje, S. (1967) J. Am. Chem. Soc. 89, 729-736

32 Fee, J. A. (1973) Biochim. Biophys. Acta 295, 87-95

33 Weser, U., Barth, G., Djerassi, C., Hartmann, H.-J., Krauss, P., Voelcker, G., Voelter, W. and Voetsch, W. (1972) Biochim. Biophys. Acta 278, 28-44

34 Rotilio, G., Calabrese, L., Bossa, F., Barra, D., Finazzi-Agro, A. and Mondovi, B. (1972) Biochemistry 11, 2182-2187 